until within a comparatively recent period. All the early chronicles abound in allusions to them-Remesal. Vasquez, Cogolludo, Villagutierre, Juarrez, and others. Uxmal and Chichen Itza, which Captain Brine speaks of as "discoveries," were undoubtedly occupied places at the time Grijalva touched the shores of Yucatan. Copan, although then a ruin, was visited and minutely described by Dr. Palacios as Iong ago as 1576 . Captain Brine would lead us to infer that these remains have been "discovered" since the expedition of Del Rio to Palenque in 1787.

That these Ruined Cities were built by the progenitors of the various families of the Tzeudal or Maya stock found in Central America at the time of the discovery, and who are still there, and that many of them were then occupied and flourishing does, not admit of doubt-is capable of demonstration.

Big-eyed Wonder should be eliminated from modern speculation!

New York, Sept. 14

E. Geo. SQUIER

\section{The Dinnington Boulder}

I HAVE been favoured with a letter from a geologist residing at Newcastle-upon-Tyne, who kindly informs me that he has inspected the "fossiliferous boulder," and pronounces it to be a block of carboniferous limestone.

This gentleman, from his knowledge of the district, says, that this limestone (underlying the coal meastres) crops out about seven or eight miles to the west or north west of Dinnington, from whence probably it came. The question asked of its direction of travel is therefore satisfactorily answered.

Barbourne, Worcester, Sept. 2 I

$$
\text { 3. BROUGH POW }
$$

\section{Mechanical Drawing}

IN the opening address of the President of the Mechanical Section of the British Association, descriptive geometry and geometrical projection are both spoken of as subjects of little value to the mechanical draughtsman.

Now, being interested in the matter, I would like to ask the nature of that special kind of mechanical drawing of which the President spoke, and which leads to mensuration and geometry. I suppose from the address, descriptive geometry and geometrical projection will be dispensed with, seeing, as he says, that it is no loss to the mechanical draughtsman to be ignorant of the latter. As an illustration of that real mechanical drawing which he advocates, would Prof. Jenkin be kind enough to show the method he would adopt in the construction of a drawing which would show the lines of intersection of the surfaces of a cone and sphere whose axes are not in the same plane?

I can assure Prof. Jenkin that a word of advice from him will always be a great boon to the hardworking student.

Fall River, Mass., Sept. 18

DRAUGHTSMAN

\section{Ice-Fleas}

I sHould have thought that the "ice-fleas" described by Prof. Frankland had been almost as familiar to Alpine travellers as their more offensive namesakes of the châlets. They are described by De Saussure (Voyages, § 2249), by. Mr. Morell, "Scientific Guide to Switzerland", p. 275 ; by myself "Alpine Regions," p. 207, where references are given, chiefly to a paper by M. Nicolet in "Neue Denkschriften der Allg. Scliweiz. Gesellsch." vol. v. (r84I) ; and by other writers on the Alps.

\section{St. John's College, Cambriage}

T. G. BONNEY

\section{Thermometer Observation}

ONE very hot day last summer I exposed to the sun, in e same position, three thermometers; No. I was a new one mounted on box wood, No. 2 was similar, but very dirty from exposure to the weather; No. 3 is what is known as a bath thermometer, with a metal scale. In the shade they all agree to about $I^{\circ}$, but in the sun No. 2 rose about $8^{\circ}$ above No $x$, and No. 3 about the same above No. 2. Here we have a discrepancy of about $16^{\circ}$, caused no doubt by the different heat absorbing and radiating powers of the substances on which the thermometers were mounted. I think this may somewhat account for the various readings we see announced by different observers.

D. J. STUART

\section{THE USE AND ABESE OF TESTS}

THE gradually increasing recognition of the claims of Science by the Government is cause for unmingled satisfaction to every one who is interested in the material and moral progress of the country. And now that the Government has set its hand to the work, it seems disposed to let no timorous counsels or half-measures prevail. The readiness with which the demands of astronomers have been met last year and this, the really admirable practical instruction recently given to science teachers at South Kensington, are evidence of the earnestness of the intentions of those in authority.

In the present attitude of the Government towards Science, however, everything is not yet as it should be. Much of the practical value of this earnestness consists in the manner in which details are carried out, and there is one department of the administration in which a spirit of mischief appears to delight in neutralising all efforts at improvement. The recent movement to compel all candidates for employment under Government to submit themselves to an educational test is in the main a good one; but it may be carried to an excessive, even to a ludicrous, extent. Tests are in themselves valueless, unless they are so contrived as to test the possession by the candidate of those qualifications which will best fit him for the office he aspires to fill.

There are at the present time vacancies in one of our Government scientific establishments for two junior assistants, and the principal of the establishment was desirous of appointing two young men who possessed the needful qualifications of neat and orderly habits, punctuality, and obliging demeanour, and a love of Science for its own sake. The establishment in question has, however, the misfortune to be under the control of the Board of Works; and when the authorities of this department heard of the vacancies, they insisted, notwithstanding the remonstrances of those most interested, in announcing them for public competition. The consequence will be that the posts will, in all probability, be given to those who display the best acquaintance with English History or French, but who have not proved themselves possessed of a single qualification for these particular posts. This Procrustean system of measuring all men by the same standard will not answer. The inevitable result will be to fill all the square holes with round men, and all the round holes with square men. As reasonably might we require all the clerks in the Foreign Office to be acquainted with the properties of the chemical elements, or every assistant in the library of the British Museum to be able to name the bones in the human skeleton; for these are as essential to the liberal education which every gentleman ought to possess, as a knowledge of English History or French. The system pursued in the British Museum, which is fortunately under the control of another department of the administration, would satisfy all reasonable requirements : that the principals of all establishments should have the right to nominate candidates to vacancies, subject to a qualification-test of their general acquirements. It is but fair that in departments where the efficiency of the subordinate officials depends so much on their willingness to co-operate heartily with their superiors, and on the possession of qualities which no examination can possibly test, the principals should have some voice in the appointment of those who may probably succeed to the offices they themselves occupy. An opportunity is thus also given for the encouragement of young scientific aspirants, who may be known as earnest and careful workers, but who would otherwise stand little chance of Government employ.

We make these strictures in no carping spirit, but simply with a desire that the good work now commenced may not be marred by errors of administration. The only object: of the system of competitive examinations, and of compelling all candidates for Government posts first to submit 